\title{
EPO verdict lifts patent coverage of seeds
}

Munich. The highest appeal board of the European Patent Office (EPO) has ruled that a patent granted to the Belgian company Plant Genetic Systems and the US biotechnology company Biogen Inc. on a procedure for producing herbicide-resistant plants through genetic engineering cannot cover the plants and seeds resulting from this process.

Although plant varieties are excluded from patentability under the terms of the European Patent Convention of 1973, this is the first time that the EPO has explicitly restricted a patent from covering a specified plant. This could have a major impact on the scope of the 100 or so patents already granted by the EPO on other genetically engineered plants - although the full impact will not be known until the EPO publishes the reasons for its decision in a few weeks.

Greenpeace, which had opposed the patent, is already claiming that the decision represents a significant victory for those who believe that life forms should not be patentable. But the plant biotechnology industry says that it is not unduly worried by the ruling; Plant Genetics Systems, for example, says that the decision will not in practice reduce its patent protection.

In 1991 Greenpeace challenged its patent, which covers a process whereby plants can be made resistant to the herbicide Basta, a glutathione synthetase inhibitor manufactured by Hoechst. The patent covered the sequence of the gene which expresses an enzyme that deactivates the herbicide, and its vector, as well as the plant cells in which the gene is expressed, and both plants expressing the gene and seeds containing it.

Greenpeace argued that the patent contravened the article in the European Patent Convention stating that patents may not be granted for "plant or animal varieties". This argument was initially rejected by the EPO's opposition division. But in a ruling last week its technical board of appeals accepted some of Greenpeace's objections, and the patent holders agreed to drop their claims for protection of plants and seeds.

At issue is the precise interpretation of the article in the convention forbidding patents on plant varieties. According to earlier EPO rulings, plants themselves are patentable because they are not excluded by this clause. But the EPO now appears to have changed its interpretation.

According to Jan van Rompaey, patent manager of Plant Genetic Systems, the appeal board may have concluded that, by definition, the term plant encompasses a group of plant varieties, and is therefore unpatentable.

According to the 1991 definition drawn up by the International Union for the Protection of New Plant Varieties (UPOV),

(from previous page) that, despite its scientific merits, could open the president to attack for supporting an illegal drug.

Wasting is a leading cause of death for AIDS patients and affects about 25 per cent of those whose immune system capacity has dropped into the 200 T-cell range. But many people who have tried Marinolan pills, an FDA-approved drug containing THC (tetrahydrocannabinol) the primary active ingredient in marijuana, say it either does not make them want to eat or it makes them so intoxicated they cannot think. Instead they turn to smoking marijuana.

Abrams started his campaign in 1992 when 'Brownie Mary', a 73-year-old San Francisco General Hospital volunteer, was arrested in nearby Sonoma County (north of San Francisco) for supplying AIDS patients with marijuana-laced brownies. With support from activists promoting the medical use of psychedelic drugs, Abrams decided to conduct a proper study.

He plans to compare the appetitestimulating effects of three doses of marijuana smoked with a water pipe to Marinol pills. The study would involve 40 people, measuring their hunger and weight gain, as well as the effects on their lungs, immune systems and the level of HIV in

\section{their bodies.}

But US state and federal governments disapprove of the smoking of marijuana for medical purposes. Pete Wilson, the governor of California, vetoed a bill last September allowing medical use of the drug. A month later, the federal government decided to maintain its ban.

Those who prefer to smoke the drug rather than take THC say that smoking is cheaper, that it is easier to control the effect on their mental capacity, and that the complex herbal compounds stimulate their appetite more than the pills.

But Abrams is still waiting for a licence from the DEA to dispense marijuana, which is rated a Schedule I substance along with heroin and LSD. He must also obtain supplies of the drug, which will require either permission from the National Institute on Drug Abuse (NIDA), or an import licence for HortaPharm, a Dutch company that Abrams says has agreed to supply him with a $\$ 50,000$-research grant, as well as all the free marijuana he needs.

Government officials accept that the use of marijuana to boost appetite merits study in part because it is relevant to an important cause of death among AIDS patients.

Sally Lehrman linked to the World Intellectual Property Organization, a United Nations body in Geneva, a plant variety is the smallest unit displaying uniform characteristics that can be distinguished within a species. "As an example," says André Heitz, a spokesman for UPOV, “ 'apple' denotes a plant species, but 'Golden Delicious' is a variety."

Plant varieties were excluded from patents under the convention because the creation of a plant variety by simple breeding was not then considered by many countries to involve a true inventive step. Exclusive protection of plant varieties was provided by the UPOV convention.

But the advent of gene technology, which introduced the possibility of creating new plants and thereby new plant varieties, by a truly inventive step, rendered the exclusion paradoxical.

Plant varieties are explicitly excluded from patenting under a proposed European Union directive on the protection of biotechnological inventions, which is being voted on by the European Parliament this week (see Nature 373, 550; 1995). The proposed directive states that "biological material, including plants and animals, as well as parts of plants and animals, except plant and animal varieties as such, shall be patentable".

It further states that "the protection conferred by a patent on a product containing or consisting of genetic information shall extend to all material in which the product is incorporated and in which the genetic information is contained and expressed".

Dominique Vandergheynst, who helped draw up the directive, says that if the directive is accepted, and consequently brought into national legislation, it will be hard for the EPO to argue that plants cannot be patented. In the future, he claims, the EPO will need to abandon its clause disallowing the patenting of plant varieties, as the basis for the distinction is no longer valid.

But he emphasizes that until the EPO's written ruling is available for study, it should not be assumed that the office has in fact assumed a position contrary to the directive. The ruling could be simply a consequence of loose wording in this particular patent, he says, whereby perhaps the description of 'plants' could be interpreted as a description of 'plant variety'.

Surprisingly, industry claims not to be concerned about last week's verdict. Tim Roberts, chairman of the biotechnology committee of the Chartered Institute of Patent Agents, and official spokesman for the senior advisory group on biotechnology to the European Chemical Industry Council, says that because claims for plant cells expressing the herbicide-resistant gene have been allowed, the overall patent protection is not diminished.

Alison Abbott 